\title{
WHOLE ROCK Pb-Pb ISOCHRON AGE FOR THE PÄ ÄKKÖ IRON FORMATION IN VÄYRYLÄNKYLÄ, SOUTH PUOLANKA AREA, FINLAND
}

\author{
MatTi SAKko and KaUko LaAjoki
}

\begin{abstract}
Sakko, Matti and Laajoki, Kauko 1975: Whole rock $\mathrm{Pb}-\mathrm{Pb}$ isochron age for the Pääkkö iron formation in Väyrylänkylä, South Puolanka area, Finland. Bull. Geol. Soc. Finland 47, 113-116.
\end{abstract}

This paper is a short comment on the first whole rock $\mathrm{Pb}-\mathrm{Pb}$ isochron age determination for the Marine Jatulian rocks of the Karelides (Middle Precambrian) in Finland. According to this method the age of the Pääkkö iron formation is $2080 \pm 45 \mathrm{Ma}$.

Matti Sakko and Kauko Laajoki, Geological Survey of Finland, SF-02150 Espoo 15, Finland.

In connection with prospecting for iron carried out in 1973 by the Exploration Department of the Geological Survey of Finland in the South Puolanka area, NE Finland, one of us (K.L.) was asked to study the stratigraphy and genesis of the small Superior-type iron-formation occurrences in Väyrylänkylä. Investigations were started in co-operation with the geochronological laboratory of the Petrological Department to solve the age of these deposits. The results are given in this paper, in which Laajoki is responsible for the geological and Sakko for the geochronological data.

The general geology of the South Puolanka area has recently been described by Laajoki (1973). Detailed studies of the Karelian (Middle Precambrian) iron formations in Väyrylänkylä are being prepared. However, since a brief description of their geology is available in another paper in this bulletin (Laajoki 1975), only $15 \quad 7352-75$ a schematic presentation of the stratigraphy of the Pääkkö iron formation (Table 1) is included in this study.

The isotopic composition of total lead was determined in core samples from a variety of rocks in the Pääkkö iron formation and from one schist in the Seppola iron formation (Table 2). The methods applied in extracting, separating and purifying the lead were as follows: The rock specimen was broken into pieces weighing from 20 to 50 grams, which were washed in $6 \mathrm{~N} \mathrm{HCl}$, rinsed with quartz-distilled water and dried. The pieces were crushed and powdered in an iron pan of a »Schwingmühle»-type mill. Five hundred $\mathrm{mg}$ of powder, a few drops of concentrated $\mathrm{HNO}_{3}$ and $4 \mathrm{ml} \mathrm{HF}$ were loaded into a teflon vessel (Krogh 1973) and heated for 48 hours in a teflon-lined steel bomb in an oven at $150^{\circ} \mathrm{C}$. The solution was evaporated twice with 1 to $2 \mathrm{ml}$ of concentrated $\mathrm{HNO}_{3}$ to dryness to destroy the 
TABLE 1

The stratigraphy of the Pääkkö iron formation in Väyrylänkylä, South Puolanka area, Finland

\begin{tabular}{|c|c|c|c|}
\hline Group & Formation & Member & Lithology \\
\hline \multirow[t]{3}{*}{ Marine Jatulian } & Dolomite-Phyllite & Salmijärvi Phyllite & $\begin{array}{l}\text { Black schist and phyllite with minor } \\
\text { quartzite intercalations }\end{array}$ \\
\hline & & $\begin{array}{c}\text { Pääkkö } \\
\text { Iron-Formation } \\
(2080 \pm 45 \mathrm{Ma})^{1)}\end{array}$ & $\begin{array}{l}\text { Quartz-magnetite-banded rock of the } \\
\text { oxide facies and quartz-siderite-banded } \\
\text { rock of the carbonate facies with phyllitic } \\
\text { intercalations. }\end{array}$ \\
\hline & & Pääkkö Quartzite & $\begin{array}{l}\text { Rather impure quartzite with phyllite } \\
\text { interbeds. }\end{array}$ \\
\hline \multirow[b]{2}{*}{$\begin{array}{c}\text { Jatulian } \\
\left.(>2050 \mathrm{Ma})^{2}\right)\end{array}$} & & Salmijärvi Dolomite & Dolomite \\
\hline & Quartzite-III & & \multirow[t]{2}{*}{$\begin{array}{l}\text { Quartzite with dolomite and phyllite inter- } \\
\text { beds. }\end{array}$} \\
\hline \multicolumn{3}{|c|}{ (Tectonic gap) } & \\
\hline \multicolumn{3}{|c|}{$\begin{array}{l}\text { PREKARELIDIC BASEMENT GNEISS COMPLEX } \\
\left.\qquad(2700-2800 \mathrm{Ma})^{3}\right)\end{array}$} & $\begin{array}{l}\text { Granodioritic or granitic orthogneisses and } \\
\text { paragneisses. }\end{array}$ \\
\hline
\end{tabular}

1) This study

$\left.\begin{array}{l}\text { 2) Laajoki } 1973 \text {, p. } 51 \\ \text { 3) Asa } 1971\end{array}\right\}$ see footnote on p. 116.

Table 2

Description of the samples analysed from the Pääkkö and Seppola iron formations

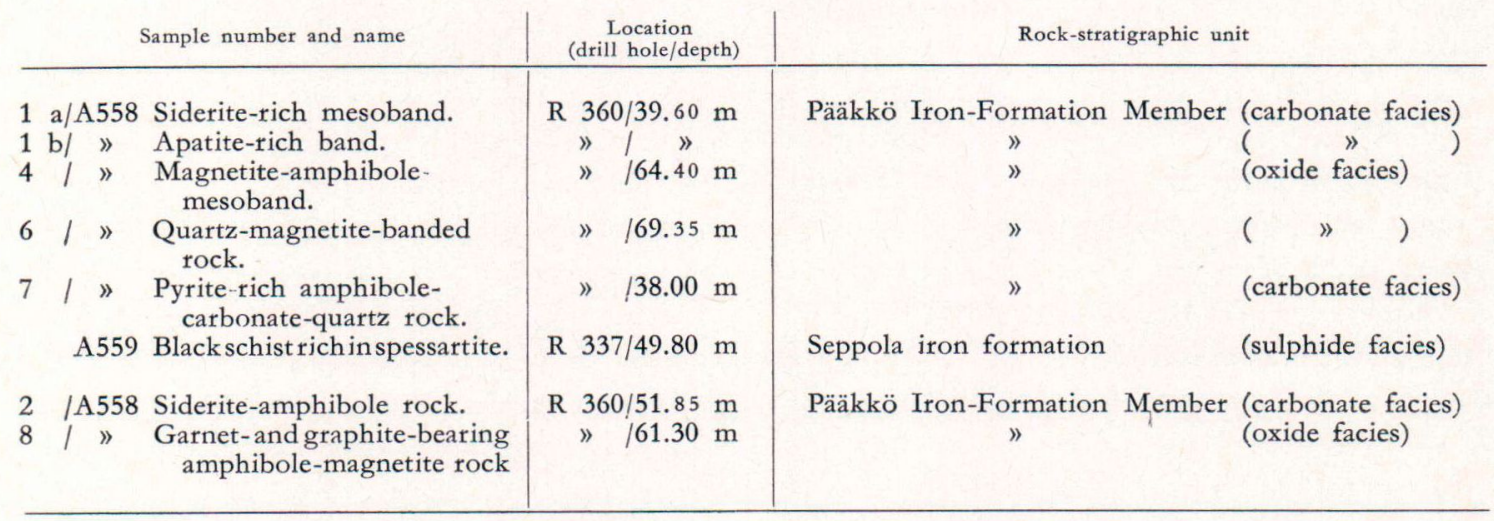


TABLE 3

Analytical Data. Sample numbers refer to TABLE 2

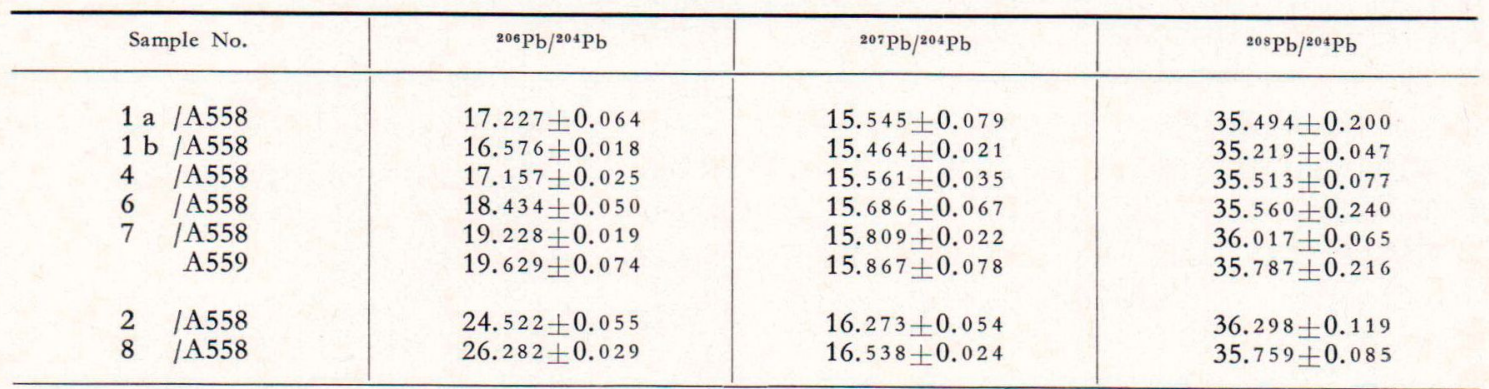

fluorides. Four ml 1.2N HBr were added and the sample was again heated at $150^{\circ} \mathrm{C}$ for 24 hours. The lead was chemically isolated by ion-exchange column. Dovex $1 \times 8,200 / 400$ mesh resin was washed twice with $1.2 \mathrm{~N} \mathrm{HBr}$ and $1.2 \mathrm{~N} \mathrm{HCl}$. Lead was eluted with $5 \mathrm{ml} 6 \mathrm{~N} \mathrm{HCl}$ and evaporated to dryness.

All isotope analyses were performed by surface ionization on a single focusing 9-inch solid source mass spectrometer with a Faraday cup using a silica gel-phosphoric acid activator on single Re filament. The mass spectrometer was intercalibrated with the CIT shelf lead (Catanzaro 1967) and all data were corrected for bias and mass fractionation.

The $\mathrm{Pb}-\mathrm{Pb}$ whole rock data (Table 3) are presented on a ${ }^{206} \mathrm{~Pb} /{ }^{204} \mathrm{~Pb}$ against ${ }^{207} \mathrm{~Pb} /{ }^{204} \mathrm{~Pb}$ plot in Fig. 1. The data define an isochron that corresponds to an age of $2080 \pm 45 \mathrm{Ma}(2 \sigma$ error) using new decay constants (Jaffey et al. 1971). The line was fitted by the method of York (1967). Data for samples 2/A558 and 8/A558 have not been used in calculating the isochron values because they define their own isochron, the slope of which is approximately the same as that in Fig. 1. This subject is being studied further.

The Marine Jatulian rocks (Dolomite-Phyllite Formation) in the South Puolanka area are interpreted to have formed under the conditions of a restricted marginal basin just before the beginning of the flysch sedimentation (Phyl- lite II) of this part of the area (Laajoki 1973) The reported age $(2080 \mathrm{Ma})$ of the Pääkkö iron formation thus gives an upper time boundary for the Karelian preflysch sedimentation in the marginal basin of the South Puolanka area. The age obtained is in good agreement with the age determination from the Karelian (Marine Jatulian) dolomite of Kalkkimaa in the Kemi area (2 $050 \mathrm{Ma}^{1}$ ), Wampler \& Kulp 1962). Earlier estimates by Kouvo and Kulp (1961) on the basis of the Karelidic galenas and by Wampler and Kulp (1964) on the basis of the Karelian pyrites indicate that the Karelian sediments deposited about $2100 \mathrm{Ma}^{1}$ ago. The age of the Pääkkö

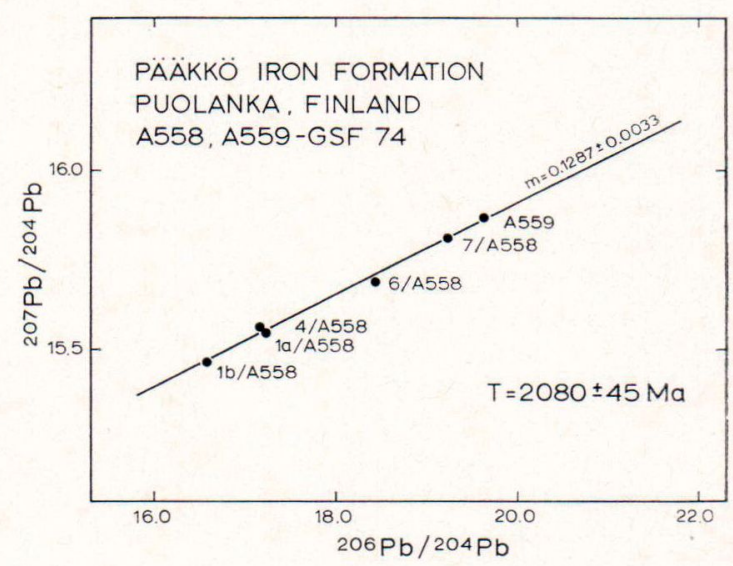

Fig. 1. $\mathrm{Pb}-\mathrm{Pb}$ whole rock plot of analytical data for the Pääkkö iron formation yielding an age of $2080 \pm 45 \mathrm{Ma}$. Sampledescription is given in TABLE 2 and analytical data in TABLE 3. 
iron formation also agrees with the minimum age $\left(2050 \mathrm{Ma}^{1}\right)$ of the Jatulian quartzites in the South Puolanka area. The latter age was indicated by the age determinations made by Sakko on zircon from the early Karelidic metadiabase intruded into the Jatulian quartzites at Latolanvaara, just $2 \mathrm{~km} \mathrm{SE}$ of Pääkkö (Laajoki 1973, p. 51). In the Kemi area the corresponding minimum age for the Jatulian quartzites is 2160 $\mathrm{Ma}^{1}$ (Sakko 1971). The oldest known U-Pb ages of zircon and sphene from the albite diabases cross-cutting the Jatulian cratogenic quartzites in Finland are $2250 \mathrm{Ma}^{1}$ ) (Matti Sakko, unpublished results and in Geological Survey of Finland 1973, p. 16).

Two galenas from carbonate-quartz-sulphide veins in the Salmijärvi Dolomite (Table 1) were analysed for their isotopic composition as follows:

$$
{ }^{206} \mathrm{~Pb} /{ }^{204} \mathrm{~Pb}
$$

${ }^{207} \mathrm{~Pb} /{ }^{204} \mathrm{~Pb}$

G 267

G 146
$14.724+0.017$

$14.861 \pm 0.012$
$15.196+0.028$

$15.204 \pm 0.017$
${ }^{208} \mathrm{~Pb} /{ }^{204} \mathrm{~Pb}$

$34.801+0.066$ $34.753 \pm 0.055$
The results indicate a common lead age of around $2200-2300$ Ma.

The iron formations in Väyrylänkylä deposited during the same time interval (2600-1800 Ma) as did the majority of the Superior-type iron formations in the world, e.g. those of the Hamersley basin, Krivoy Rog and the Lake Superior region (Goldich 1973).

1) If the new decay constants (Jaffey et al. 1971) were used, the ages would be approximately $30 \mathrm{Ma}$ lower.

Acknowledgements - The authors are indebted to the following staff members of the Geological Survey of Finland: Dr. Olavi Kouvo for valuable suggestions and help during the study, Mrs. Marita Niemelä and Tuula Hokkanen and Mr. Timo Lahti for skilled technical assistance, Mr. Matti Vaasjoki, M. Sc., for automatic data prosessing programs and Mrs. Anni Vuori for drawing the figure.

\section{REFERENCES}

AsA,M. (1971) Radiometrisiä iänmäärityksiä Kainuusta. (Radiometric age determinations from Kainuu). Master's thesis, Manuscript at the Department of Geology, University of Helsinki.

Catanzaro, E. J. (1967) Absolute isotopic ratios of three common lead reference samples. Earth and Planet. Sci. Lett. 3: 343-346.

Geological Survey of Finland (1973) Annual report on the activities for the year 1972 (in Finnish with an English summary). 59 p.

Goldich, S.S. (1973) Ages of Precambrian banded iron-formations. Econ. Geol. 68: 1126-1134.

Jaffey, A. H.; Flynn, K. F.; Glendenin, L. E.; BentLEY, W. C. and Essling, A. M. (1971) Precision measurement of half-lives and specific activities of ${ }^{235} \mathrm{U}$ and ${ }^{238} \mathrm{U}$. Phys. Rev. 4, p. 1889.

Kouvo, O. and Kupl, J. L. (1961) Isotopic composition of Finnish galenas. Ann. N. Y. Acad. Sci. 91: 476491.

KRoGH, T. E. (1973) A low-contamination method for hydrothermal decomposition of zircon and extraction of $\mathrm{U}$ and $\mathrm{Pb}$ for isotopic age determinations. Geochim. Cosmochim. Acta 37: 485-494.

LAAJOKI, K. (1973) On the geology of the South Puolanka area, Finland. Geol. Surv. Finl. Bull. 263. 54 p.

- (1975) Rare-earth elements in Precambrian iron formations in Väyrylänkylä, South Puolanka area, Finland. Bull. Geol. Soc. Finland. 47: 93-107.

SAKко, M. (1971) Varhais-karjalaisten metadiabaasien radiometrisiä zirkoni-ikiä. (Radiometric zircon ages on the Early-Karelian metadiabases, in Finnish with an English summary). Geologi 23: 117-118.

Wampler, J. M. and Kulp, J. L. (1962) Isotopic composition and concentration of lead in some carbonate rocks. Geol. Soc. Am., Petrological studies: a volume in honor of A. F. Buddington 105-114.

Wampler, J. M. and Kulp, J. L. (1964) An isotopic study of lead in sedimentary pyrite. Geochim. Cosmochim. Acta 28: 1419-1458.

York, D. (1967) The best isochron. Earth and Planet. Sci. Lett. 2: $479-482$.

Manuscript received, February 11, 1975. 